\title{
Philosophical and Economic Aspects of Cultural Tourism
}

\author{
Jaroslav KACETL \\ University of Hradec Králové, Hradec Králové, Czech Republic \\ jaroslav.kacetl@uhk.cz
}

\begin{abstract}
This study is a part of a more detailed research attempting to better understand the phenomenon of travel and tourism. This particular contribution was motivated by growing significance of cultural tourism. Its aim was to find out what the term cultural tourism stands for, what tourists may be labelled as cultural tourists, what issues belong to the core of this phenomenon, and, last but not least, what economic potential cultural tourism has. Cultural tourism covers a lot of different phenomena, often depending on personal opinion. It seems to escape all efforts to clearly define its meaning as it refers to a lot of tourist activities. There are several classifications of cultural tourists, who often participate in other activities, too. The most significant phenomenon linked to cultural tourism is authenticity. Last but not least, the number of scientific texts on cultural tourism has been rising but it is still unclear how to quantify its economic impacts.
\end{abstract}

Keywords: Cultural Tourism, Cultural Tourist, Authenticity, Tourism Satellite Account.

\section{Introduction}

As Richards [13] puts it, view cultural tourism is viewed by policy makers, tourist boards and cultural attraction managers around the world as a significant potential source of tourism growth. The European Commission [5] states that cultural tourism accounts for some $40 \%$ of all European tourism. Cultural tourism covers a lot of different phenomena, often depending on personal opinion. It may focus on the issues of cultural identity, problems of space and place, it may feature such diverse things like great personalities, arts, religion, cuisine, sports, or industrial sites. It also includes urban tourism and the so-called festivalization of society linked to both traditional and newly-established events, highlighted by various projects like the European Capitals of Culture.

Initially, several questions connected to cultural tourism were identified. For instance, Richards [Chyba! Nenalezen zdroj odkazů.] can see three essential questions about cultural tourism - namely: Who are the cultural tourists? What are their motivations? Where do they go? - and adds that it is still different to answer them. This study, however, aims to answer slightly different research questions, namely: 
- What does the term cultural tourism stand for?

- What tourists may be labelled as cultural tourists?

- What issues belong to the core of this phenomenon?

- Is cultural tourism an attractive research paper topic?

- What is the economic impact of cultural tourism?

\section{Methodology}

In order to answer the research questions, following research method were employed. Literature survey was used to find out relevant studies about cultural tourism. Then, selected sources were studied in more detail in order to highlight the most significant issues. The identified areas of interest were used to ask research questions and then further studied in selected sources.

Another method was statistical. Two databases, namely Web of Science and ScienceDirect [14] were searched for the number of studies in whose titles there were used words 'cultural tourism' in each of the ten years between 2008 and 2017. This approach was employed in order to find out whether or not the number of studies on cultural tourism has been rising and at the same time it helped the author determine the most relevant literature in this area.

\section{Results}

\section{Definition of Cultural Tourism}

There is no undisputed definition of cultural tourism. According to Mousavi et al. [7] the problem of defining cultural tourism reflects a complex relationship between culture and tourism. Richards [Chyba! Nenalezen zdroj odkazů.] states that proposing definitions of cultural tourism may lead to endless discussions about the definition of culture. Nevertheless, the same author provides two definitions of cultural tourism elsewhere [Chyba! Nenalezen zdroj odkazů.], a conceptual definition: 'the movement of persons to cultural attractions away from their normal place of residence, with the intention to gather new information and experiences to satisfy their cultural needs', and a technical one: 'all movements of persons to specific cultural attractions, such as heritage sites, artistic and cultural manifestations, arts and drama outside their normal place of residence' [12]. There are other definitions of cultural tourism by other authors, too.

For instance, Silberberg [15] understands cultural and heritage tourism as the 'visits by persons from outside the host community motivated wholly or in part by an interest in the historical, artistic, scientific or lifestyle/heritage offerings of a community, region, group or institution' [15]. Yun et al [19] use the following definition: 'cultural tourism covers all aspects of travel where visitors can learn about another area's history and way of life'. This list of definitions is by no means 
complete, which only emphasizes the aforementioned problems with determining the clear meaning of cultural tourism.

This problem is further aggravated by the fact cultural tourism has changed significantly. Nowadays, not only are there different approaches to cultural tourism in different countries and on various continents, but also cultural tourists may be divided into distinct groups (e.g. [Chyba! Nenalezen zdroj odkazů.1], [4]). Whereas in the 17 th and 18th centuries the Grand Tour was exclusively for the elite, current cultural tourism is for almost everybody and covers various activities and experiences [4]. Debes [4] adds it is cultural tourism, albeit under various labels like ethnic, shopping, gambling, theme, hallmark, event, Olympic, craft as well as material and immaterial culture, where trendsetters are currently focusing their attention. Richards [Chyba! Nenalezen zdroj odkazů.1] states that 'the classic image of cultural tourism still seems strongly tied to the European model of passive consumption of historic sites and museums'. The same author [11] maintains that whereas in the past cultural tourism was largely associated with high culture and the heritage associated with cultural tourism was largely fixed and tangible, the current cultural tourism includes mobile and intangible products of contemporary culture' [11].

According to Mousavi et al. [7] there is little doubt that culture is a key component of tourism product and it to a great extent determines the competitiveness and effectiveness of tourism destinations. These authors [7] add that cultural tourism is associated with both visiting monuments and sites (i.e. consuming products of the past) and consuming the contemporary way of life and culture of local people in different destinations.

Bína [2] distinguishes in his methodology of assessing touristic potential of Czech Republic's settlements two components of touristic potential, natural and cultural. The latter includes cultural and historical sights, open-air folk museums, spas, congresses and conferences, cultural events, sports events, religious events, trade fairs and thematic markets, local products and border town specifics.

In conclusion, cultural tourism seems to escape any efforts to clearly pinpoint its meaning. On the contrary, it may accumulate new meanings as it has been spreading across the globe. People living outside Europe, the cradle of cultural tourism, tend to view and approach cultural tourism differently, with suggests that there is a huge potential for further widening the concept of cultural tourism, rather than making it narrow and clear.

\section{Cultural Tourist}

Cultural tourism entails the existence of cultural tourists differing from general visitors. Who are the cultural tourists, then? They are no longer a homogenous group of travellers as they might have been in the times of Grand Tours, which marked the beginning of cultural tourism. There has already been argued that cultural tourism itself has been expanding from the elite to almost everybody, from Europe to the whole world, from the fixed and tangible to the mobile and intangible. This suggests that the cultural tourist of the past was much different from the current one. This divergence is however balanced by a convergence, which looms as a threat the 
encroaching cultural globalization. Cultural forms have become globalized through the growth of personal mobility, expansion of the Internet and the media [11]. According to Debes [4], there are those who warn that global forces destroy authentic culture and identity and others who deem culture and identity as a worthwhile commodity.

There are several classifications of cultural tourists as for example Yun et al. [19] show. As Alzua et al.[1] argue, cultural tourists are a heterogeneous group pursuing a wide range of culture and heritage related activities, including visiting places of historical interest, places of military significance, sites commemorating important people, places with religious significance, and those of archaeological interest as well as enjoying ethnic culture and events, arts and cultural attractions, museums and galleries, attending local festival, fairs, and other events, and sightseeing in cities.

According to McKercher and du Cros [6] some researchers, like use demographic variables to identify what makes cultural tourists different from other ones, whereas other researchers prefer benefit segmentation. Kercher and du Cros (2003), however, examine centrality of cultural motives in selecting the destination as culture may be the primary or only secondary reason or even may not play any role at all. McKercher and du Cros [6] identified five types of cultural tourists: the purposeful one for whom culture is the main concern; the sightseeing cultural tourist focusing on cultural highlights; the casual one, not much involved in experiencing culture; the incidental cultural tourist who is superficially interested; and the serendipitous one, who does not deem cultural experience important but may find it accidentally enticing. These five segments tend to seek various types of experience and aim to gain various amounts of knowledge.

According to Nyaupane, Morais and Dowler [9], motivation of tourists in relation to cultural consumption may be classified as culture-focused, culture-attentive, and culture-appreciative.

As Nyaupane and Andereck [8] suggest, tourists visiting cultural heritage attractions can be divided into 'true cultural heritage tourists' and 'spurious cultural heritage tourists.' The former can be subgrouped into 'tangible heritage' and 'intangible heritage' tourists, whereas the latter into 'nature,' 'sport,' and 'business' tourists.

In conclusion, defining cultural tourism and cultural tourists is complicated as it means different things to different people [6]. As Yun et al. [19] maintain, it produces problems since it contains a wide range of cultural elements and it is not clear what kinds of cultural experiences should be included within the scope of cultural tourism. On the other hand, Yun et al. [19] add that cultural tourists participate in other activities, especially those related to nature, recreation, and entertainment, which leads them to the conclusion that cultural tourism should be integrated with other activities.

All in all, the centrality of cultural tourism as a trip motive and the depth of experience - as they are suggested by McKercher and du Cros [6] - seems to be an important issue in attempts to pinpoint the nature of cultural tourists. 


\subsection{Core Phenomena of Cultural Tourism}

There are only few studies focusing on philosophical aspects of cultural tourism. Nonetheless, core phenomena of cultural tourism should be viewed as an important topic, too.

The most significant phenomenon mentioned in literature is authenticity. For instance, Wang [16] attempted to clarify the concept of authenticity in tourist experiences. Wang [16] sees three different approaches to authenticity - objective, constructive and essential. Objective authenticity uses an absolute criterion to measure authenticity, i.e. whether toured objects are original or fake. Constructive authenticity is according to Wang [16] also refers to toured objects but their authenticity is projected onto them by either tourists themselves or by someone else in terms of their points of view, beliefs, perspectives, expectations, preferences, interpretations, imagery, or else. Whereas the two above-mentioned approaches are object-related, existential authenticity is activated by tourist experience. Activities like camping, picnicking, mountaineering, or adventures contrast with the mundane. Wang [16] also distinguishes between intra-personal and inter-personal authenticity. Within intra-personal authenticity he further differentiates bodily feelings and selfmaking. The former is linked to, among other ones, relaxation, recreation, entertainment, refreshment, or excitement, whereas the latter suggests pursuing selfrealization in risky and challenging activities like mountain-climbing, or oceancruising. Inter-personal authenticity is divided into two categories, namely family ties and touristic communitas. Family tourism may reinforce its members' togetherness. Communitas, as Wang [16] puts it, occur as an unmediated inter-personal relationship among pilgrims.

Richards [11] also reflects on the emergence of everyday or mundane as a source of authentic experience in tourism. In our everyday lives we develop skills and certain actions become automatic and in a way invisible, which is one reason why travel to other places is pleasurable as it provides us with new experiences and activities we need to focus on. Richards [11] also mentions other themes. For example, the dichotomy between real places and non-places points at the difference between the phenomenon of placefulness and that of placelessness. Richards [13] maintains that the raised interest in the concept of place indicates that the study of cultural tourism is following the spatial turn in the social sciences. Richards [13] summarizes that the experts seem to adopt either of the two approaches to place and placelessness, namely either a sense of loss for 'real' places, which links to authenticity, or an increasing desire for non-places represented by the mundane and everyday life, or by the McDonaldization of society.

Another discussed topic is the relation between culture and identity. Richards [13] realizes that experts write about conflicts over the 'ownership' of culture and the shifting boundaries of culture and economy. Richards suggests that perhaps 'everyday life' becomes 'culture' and adds we should ask the following questions: Are people looking for distinctiveness rather than difference? Are they looking for new distinctions, or simply more distinct experiences? 
Whereas difference suggests certain relations between things, in case of tourism it is usually a relation between one's home and the destination, the word 'dictinction' hints at the fact that a destination may boast of a particular quality not to be found elsewhere. Richards [13] considers the focus on what might be distinct about places as an interesting development because tourism has usually been linked to the 'extraordinary' but the word 'distinct' suggests some aspect of the local, which is seen by local people as mundane or everyday routine, constitutes the sense of place or its authentic essence. In other words, local people's everyday life is tourists' adventure.

\subsection{Cultural Tourism as Research Paper Topic}

As this study is based on literature review of the area of cultural tourism, one of the author's aims was to find out recent and relevant research papers on cultural tourism. Two scientific websites were searched, namely Web of Science [17] and ScienceDirect [14]. In case of Web of Science, basic search for 'cultural tourism' in 'Title' was applied for individual years between 2008 and 2017 (as of 26th October 2017), that is in the last ten years. ScienceDirect [14] was searched as well. It was an advanced search in 'All' (i.e. books, journals, etc.) for 'cultural tourism' in 'Title' for all sciences in individual years between 2008 and 2017 (as of 26th October 2017), that is in the last ten years. The resulting numbers of research papers are listed in Table 1 .

Table 1. Texts on cultural tourism as of 26th October 2017.

\begin{tabular}{lcl}
\hline Year & $\begin{array}{l}\text { Number of texts on cultural } \\
\text { tourism - Web of Science }\end{array}$ & $\begin{array}{l}\text { Number of texts on cultural } \\
\text { tourism - ScienceDirect }\end{array}$ \\
\hline 2017 & 114 & 10 \\
2016 & 208 & 9 \\
2015 & 152 & 17 \\
2014 & 125 & 12 \\
2013 & 103 & 5 \\
2012 & 101 & 10 \\
2011 & 89 & 15 \\
2010 & 113 & 3 \\
2009 & 81 & 5 \\
2008 & 53 & 6 \\
\hline
\end{tabular}

As Table 1 shows, the number of texts on cultural tourism has been rising. The difference between the 2008 and 2017 figures is clear although the latter year has not ended, yet. The respective results for Web of Science [17] and ScienceDirect [14] slightly vary, though. Consequently, it is not possible to assess the extent of the rise. Moreover, there is another pitfall, namely the fact that the search results included 
articles whose titles used the searched words 'cultural' and 'tourism' without any direct relationship. It would be therefore useful to elaborate the way of looking for articles on 'cultural tourism'.

\subsection{Economic Impact of (Cultural) Tourism in the Czech Republic}

Initially, it was intended to gather statistical data on cultural tourism in the Czech Republic. Authors (e.g. [4], [11], and [10]) usually maintain that the utilization of culture in tourism has positive impact on the local economy as it helps create new jobs, and it also strengthens local identity and social cohesion. Plzáková [10] contends that the 2009 Eurobarometer survey determined cultural attractiveness as the second most significant motivation - after value for money - for European tourists in selecting their holiday destination. Although there are various methods of measuring how tourism contributes to the economic growth, including the input-output analysis or the tourism satellite account (TSA), it is nonetheless difficult to measure its impact (e.g. [10]).

These difficulties have manifested themselves in the fact that the attempt to find any statistics on cultural tourism in the Czech Republic brought no results. It was therefore decided to focus on accessible data on tourism in general instead. The aforementioned TSA gathers data on both tourism and the economy in order to determine the contribution of tourism in e.g. gross value added, gross domestic product and other indicators [18]. The Czech Statistical Office [3] has been doing the TSA for the Czech Republic since 2003.

Table 2. Main indicators of the national economy and tourism in the Czech Republic between 2003 and 2015 Tourism ratio on the Czech Republic's gross domestic product [3].

\begin{tabular}{llcl}
\hline Year & $\begin{array}{l}\text { Tourism ratio on } \\
\text { gross value added } \\
(\boldsymbol{\%})\end{array}$ & $\begin{array}{l}\text { Tourism ratio on } \\
\text { gross domestic } \\
\text { product }(\boldsymbol{\%})\end{array}$ & $\begin{array}{l}\text { Tourism gross } \\
\text { domestic product } \\
\text { (CZK mil.) }\end{array}$ \\
\hline 2003 & 3.4 & 3.5 & 90792 \\
2004 & 3.3 & 3.6 & 102316 \\
2005 & 3.0 & 3.3 & 99079 \\
2006 & 2.9 & 3.1 & 99956 \\
2007 & 2.7 & 2.9 & 103079 \\
2008 & 2.6 & 2.8 & 103451 \\
2009 & 2.7 & 2.9 & 104293 \\
2010 & 2.6 & 2.7 & 100253 \\
2011 & 2.6 & 2.7 & 102275 \\
2012 & 2.6 & 2.7 & 111399 \\
2013 & 2.8 & 2.9 & 117932 \\
2014 & 2.7 & 2.8 & 117878 \\
2015 & 2.7 & 2.8 & 126323 \\
\hline
\end{tabular}


Table 2 does not illustrate the impact of cultural tourism as attempts to find any relevant data were futile. It therefore provides general information on tourism in the Czech Republic. It indicates, for instance, that whereas nominal tourism GDP has been rising - from about 91 million CZK in 2003 to about 126 million in 2015, tourism ratio on both gross value added and gross domestic product has fallen from about $3.5 \%$ to below $3 \%$. However, data collection for cultural tourism, particularly on the regional level, is a complex issue with the ticketing system being one of its few advantages. These difficulties are one of the reasons for UNWTO and other international bodies [18] to organize Workshop on Measuring the Economic Impact of Tourism in Europe: the Tourism Satellite Account (TSA) in November 2017.

Plzáková [10] emphasizes that the potential of cultural tourism has both direct and indirect impacts on the economy and adds that the economic impact of cultural tourism is most often considered when it comes to state (region, place), gross domestic product, employment and public budgets.

\section{Discussion}

This study, aimed to answer five research questions. The first two asked about the meaning of terms 'cultural tourism' and 'cultural tourists'. Literature review showed that defining cultural tourism and cultural tourists is complicated as it means different things to different people [6]. Cultural tourism seems to escape any efforts to clearly pinpoint its meaning. On the contrary, it may accumulate new meanings as activities labelled as cultural tourism have been spreading across the globe. It seems that in attempts to pinpoint the nature of cultural tourists it is necessary to put cultural tourism as a trip motive and the depth of experience as the main motive, it is suggested by McKercher and du Cros [6].

Concerning philosophical views of the core of cultural tourism, the concepts of authenticity and its meanings prove to be the most significant issue, followed by those of culture, identity, placefulness, and distinction.

Another research question was to show whether the number of scientific texts on cultural tourism has been rising. Statistical analysis done on Web of Science [17] and ScienceDirect [14] databases showed that the number of such texts has risen significantly.

Last but not least, the study asked about the economic impact of cultural tourism. There are ways of measuring this impact but they are still flawed. Nonetheless, international bodies, like UNWTO, as well as national ones, like the Czech Statistical Office in the Czech Republic, have been using and promoting various methods, most significantly the TSA. Admittedly, it is not easy to determine and apply the methodology of gathering information needed to assess the impact of cultural tourism on tourism in general and, consequently, there is a lack of statistics on cultural tourism. 


\section{Conclusion}

This study shows that cultural tourism is an ethereal phenomenon that defies definition as well as exact measurement. Travelling and consequently cultural tourism has been changing due to the technological development, too. Currently, unprecedented developments in personal mobility make it much easier to travel than ever before, social media streamline communication and exchange of tourism-related information as well as ideas among people. Globalization changes cultural tourism as well as cultural tourists.

Another consequential fact is that international as well as national organizations are aware of the importance of linking tourism and culture as this connection may generate economic advantages for countries and regions that manage to exploit the fact that culture appeals to tourists and makes them choose a particular destination.

Acknowledgements. This article is supported by the Internal Grant Project of the Faculty of Informatics and Management, University of Hradec Kralove, called 'Zkvalitňování výuky $\mathrm{v}$ anglickém jazyce a podpora publikační činnosti v oblasti cestovního ruchu', ID: 1903.

\section{References}

1. Alzua, A, O'Leary, J. T., Morrison, A. M.: Cultural and Heritage Tourism: Identifying Niches for International Travelers. The Journal of Tourism Studies 9(2), 2-13 (1998).

2. Bína, J.: Hodnocení potenciálu cestovního ruchu v obcích České republiky. Urbanismus a územní rozvoj 5(1), (2002).

3. Czech Statistical Office: TSA - Main indicators of the national economy and tourism in the Czech Republic, https://www.czso.cz/csu/czso/tsa_main_indicators_of_the_national_economy_and_tourism_i n_the_czech_republic, last accessed 2017/11/03.

4. Debes, T.: Cultural Tourism: a Neglected Dimension of Tourism Industry. Anatolia - An International Journal of Tourism and Hospitality Research, 22(2), 234-251 (2011).

5. European Commission: Cultural Tourism http://ec.europa.eu/growth/sectors/tourism/offer/cultural_en, last accessed 2017/10/26.

6. McKercher, B., du Cros, H.: Testing a Cultural Tourism Typology. International Journal of Tourism Research 5(1), 45-58 (2003), DOI: 10.1002/jtr.417.

7. Mousavi, S. S., Doratli, N., Mousavi, S. N., Moradiahari, F.: Defining Cultural Tourism. In: International Conference on Civil, Architecture and Sustainable Development, Dec. 2016, pp. 70-75, CASD, London (2016).

8. Nyaupane, G. P., Andereck, K. L.: Visitors to Cultural Heritage Attractions: An ActivityBased Integrated Typology. Tourism, Culture and Communication 14(1), 17-26 (2014) DOI: 10.3727/109830414X14038917832824.

9. Nyaupane, G. P., Morais, D. B., and Dowler, L.: The role of community involvement and number/type of visitors on tourism impacts: A controlled comparison of Annapurna, Nepal and Northwest Yunnan, China. Tourism Management 27(6), 1373-1385 (2006). 
10. Plzáková, L.: The Economic Impact of Cultural Tourism Measured through the Interconnection of the Tourism Satellite Account and Satellite Account on Culture. In: 12th Global Forum on Tourism Statistics, GFTS, Prague (2014)

11. Richards, G.: Cultural Tourism: Global and Local Perspectives. 2nd edn. The Haworth Hospitality Press, NewYork, London, Oxford (2007).

12. Richards, G.: Cultural Tourism in Europe. 1st edn. CAB International, Wallingford (1996).

13. Richards, G.: What is Cultural Tourism? In: van Maaren, A. (ed.) Erfgoed voor Toerisme Stichting Nationaal Contact Monumenten, Amsterdam (2003).

14. ScienceDirect. http://www.sciencedirect.com/science/search, last accessed 2017/11/03.

15. Silberberg, T.: Cultural Tourism and Business Opportunity for Museum and Heritage Sites. Tourism Management 16(5), 361-365 (1995).

16. Wang, N.: Rethinking Authenticity in Tourism Experience. Annals of Tourism Research 26(2), 349-370 (1999),DOI: 10.1016/S0160-7383(98)00103-0.

17. Web of science. http://apps.webofknowledge.com/WOS_GeneralSearch_input.do?product=WOS\&search_mo $\mathrm{de}=$ GeneralSearch\&SID=Z1OsssrxUYCFLxly2iS\&preferencesSaved $=$, last accessed 2017/11/03.

18. World Tourism Organization: Workshop on Measuring the economic impact of tourism in Europe: the Tourism Account http://statistics.unwto.org/event/DG_Grow_WS, last accessed 2017/11/03.

19. Yun, D., Hennessey, S., MacDonald, R., MacEachern, M.: Typology of Cultural Tourists: An Island Study. In: Novaczek, I. (eds.) Culture and the Construction of Islandness, June 29-July 2, 2007, pp. 101-111, SICRI, Charlestown (2008). 